\title{
Symptomatology and Anatomy of Stemgrooving (Legno Riccio) in the Grape Vine
}

\author{
G. J. le R. Kriel,(1) C. J. Orffer, ${ }^{(2)}$ and E. F. Beukman ${ }^{(3)}$ \\ (1) Chief Viticulturist, KWV, Suider-Paarl, 7624 \\ (2) Professor, Department of Viticulture, University of Stellenbosch, 7600 \\ (3) Production Manager (Development), KWV, Suider-Paarl, 7624 \\ Abstract from M.Sc. Agric. thesis by the first author, University of Stellenbosch, December 1973.
}

\begin{abstract}
External and anatomical differences between organs affected and unaffected by stemgrooving were studied on the wine grape cultivar Chenin blanc and the table grape cultivars Barlinka and Almeria. Cultivar susceptibility, graft transmissibility as well as the effect of the disease on the percentage of take and growth in the nursery were studied. The probability of an association with other virus diseases was considered. Abnormal behaviour of the vascular cambium of infected vines gave rise to hypertrophy, hyperplasia, hypoplasia and parenchymatoses in the secondary xylem and phloem. In diseased tissues differentiation of phellogen proceeded abnormally deep into the phloem rays. Graft transmission was detected anatomically within six months. The disease was found in all the vine growing districts of the Western Cape. Anatomical studies showed that the disease had been present for many years. A negative effect on the percentage of take and growth in the nursery was recorded. A probable-relationship with corky bark was indicated anatomically and by indexing with LN33.
\end{abstract}

Stemgrooving (GS) or legno riccio, a virus or viruslike disease of the vine, was first described in 1959 near Taranto in South Italy (Graniti, 1964). The disease (or similar diseases) has since been reported to occur in Israel (Hewitt, 1965), France (Vuittenez, 1970), Hungary (Lehoczky, et al., 1968), Switzerland (Bovey, 1971, personal communication), California (Hewitt \& Neja, 1971), Greece (Agrios, 1971) and Bulgaria (Abrasheva, Penka \& D. Tsvetanov, 1970).

In South Africa it was observed in 1969 on Cardinal, grafted on Vitis Rupestris var. du Lot at Stellenbosch (Engelbrecht \& Nel, 1971). Field observations in Italy (Graniti \& Martelli, 1970) and Greece (Agrios, 1971) indicated that the disease may be soil borne. Hewitt (1970) indicated that the disease may be caused by a strain of fanleaf or a combination of viruses. Vuittenez (1970) is of the opinion that leafroll may play a role in GS symptoms, whilst according to Goheen (1971, personal communication) the disease resembles corky bark. Several similar stemgrooving diseases like "tristeza" on citrus (Oberholzer, Mathews \& Stieme, 1949), "apple stemgrooving"' (Guengerich \& Millikan, 1956) and "stempitting" of Prunus (Mircetich, Figle \& Barrat, 1968) are caused by the semi-latent group of "chlorotic leafspot"' viruses (Vuittenez, 1970).

The objects of the study were to describe the external symptoms of GS, to investigate the anatomic changes caused by the disease in the different organs and tissues of the vine, and to test the susceptibility of different cultivars of the vine by means of graft transmission trials. Graniti \& Martelli (1965) detected symptoms only in the second and third year after grafting.

\section{MATERIALS AND METHODS}

External and macroscopical symptoms: External symptoms were described for the following and compared with the descriptions of Graniti (1964) on Primitivo di Gioia:

1. Chenin blanc grafted on Jacquez at Paarl.
2. Barlinka grafted on Jacquez at De Doorns.

3. Almeria grafted on Vitis Rupestris var. du Lot at De Doorns.

4. Alphonse Lavallée grafted on Jacquez at De Doorns.

5. Queen of the Vineyard (Regina dei Vigneti) grafted on Jacquez in Paarl.

In order to obtain an indication of the effect of the disease on vine vigour, the cane mass was determined for 14 stemgrooving diseased (GSa) vines and 14 vines visually free from stemgrooving (GSo), randomly selected in the Chenin blanc on Jacquez vineyard.

Anatomical Symptoms: Samples as described below were periodically collected from GSa and GSo vines in vineyards 1,2 and 3 above. Additional samples were collected from Chenin blanc on Jacquez (Rawsonville), Waltham Cross on Jacquez (Paarl), Queen of the Vineyard on Jacquez (Paarl), as well as Cardinal grafted on Rupestris var. du Lot at Stellenbosch. Nursery vines bud grafted with GSa and GSo buds were also sampled.

Rectangular blocks of tissue $15 \mathrm{~mm} \times 10 \mathrm{~mm} \times 10 \mathrm{~mm}$ were sampled as described by Kriel (1973) on fixed locations on the stem. Fifteen $\mathrm{mm}$ transversal segments of the roots, shoots and leaf petioles were also sampled as described by Kriel (1973). All material was fixed in formaline-acetic acid-alcohol (FAA) for tissue investigations and in chrome-acetic-formalin (CRAF) for cytological studies. Blocks of woody material were cut in an unimbedded state with a sliding microtome. Soft material like roots, petioles and young shoot internodes were dehydrated and imbedded according to the method of Johansen (1940) and sectioned with a rotating microtome. The safranine, fast green staining technique (De Vos, 1962) was utilised. Staining for cytological studies was done with Sudan IV, according to the method of Brookes, Bradley \& Anderson (1963). Iodine was used to determine whether or not starch was present. Macerations for investigation of conducting elements was done as described by Jefferey (Johansen, 1940) and stained with 1\% safranine. Prepared material was mounted in Canada balsam. 
Susceptibility of cultivars and graft transmission: Ten cuttings each of ten rootstock and four scion cultivars visually free from stemgrooving (GSo) were planted in 500 $\mathrm{ml}$ pots in a greenhouse in August, 1971. Details of the material used are indicated in Table 1.

TABLE 1

Details of material used in the transmission trials

\begin{tabular}{|c|c|c|c|c|c|c|}
\hline \multirow{2}{*}{ Cultivar } & \multirow{2}{*}{ Clone } & \multicolumn{5}{|c|}{ Virus content } \\
\hline & & $\mathrm{N}$ & V & $\mathrm{K}$ & $\mathrm{R}$ & GS \\
\hline 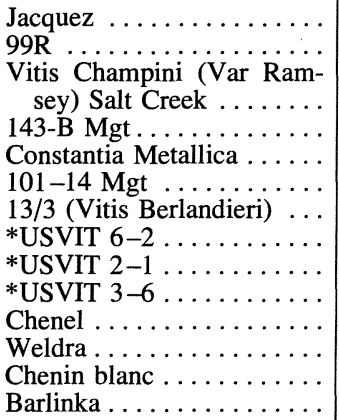 & $\begin{array}{l}\text { J5/9/24 } \\
99 \mathrm{R} / 1 / 1 / 13 \\
\mathrm{Sc} 5 / 19 / 5 \\
\mathrm{~B} 5 / 32 / 11 \\
\mathrm{Me} 1 / 2 / 1 \\
\mathrm{~A} 1 / 1 / 5 \\
- \\
\\
\\
\mathrm{K} 1 / 4 / 51 \\
\mathrm{~K} 2 / 6 / 31 \\
\mathrm{~S} 4 / 21 \\
\mathrm{~B} 4 / 2\end{array}$ & $\begin{array}{l}- \\
- \\
- \\
- \\
- \\
0 \\
- \\
- \\
- \\
- \\
- \\
0\end{array}$ & $\begin{array}{l}- \\
- \\
- \\
- \\
\bar{o} \\
- \\
- \\
- \\
- \\
+ \\
+\end{array}$ & $\begin{array}{l}- \\
- \\
- \\
- \\
- \\
- \\
0 \\
- \\
- \\
- \\
- \\
- \\
-\end{array}$ & $\begin{array}{l}+ \\
- \\
- \\
- \\
- \\
\overline{0} \\
- \\
- \\
+ \\
+ \\
+\end{array}$ & $\begin{array}{l}- \\
- \\
- \\
- \\
- \\
- \\
- \\
- \\
- \\
- \\
- \\
- \\
- \\
-\end{array}$ \\
\hline Symbols: $\quad \begin{aligned} \mathrm{N} & =\text { fanleaf } \\
\mathrm{V} & =\text { fleck } \\
\mathrm{K} & =\text { corky bark } \\
\mathrm{R} & =\text { leafroll } \\
\mathrm{GS} & =\text { stemgroovir }\end{aligned}$ & $\begin{array}{r}+= \\
-= \\
0= \\
*=\end{array}$ & & & & & \\
\hline
\end{tabular}

During October, 1971, seven of the ten rooted plants of each cultivar were bud grafted with GSa Chenin blanc buds. The buds originated from a visually selected GSavine. The remaining three plants of each cultivar were grafted with GSo Chenin blanc buds from a healthy vine, in the same vineyard. The vines were put in a shade house during November, 1971 and visually inspected for symptoms in June, 1972.
One successfully grafted vine was sampled in August, 1972 for anatomical investigations as follows: the main root; $10 \mathrm{~mm}$ below the graft union; $10 \mathrm{~mm}$ above the graft union; the first and third internode (acropetally) and permanent slides were prepared. The remaining vines with viable graftings were planted in the field. During March, 1973 a survey of the visually perceptible symptoms was made and 3 months later one vine of each treatment was sampled as outlined above.

In order to obtain an indication of the occurrence of this disease in the Western Cape, spot checks were made on a wide range of cultivars in all the grapegrowing districts. A shallow diagonal cut was made below and above the graft union and the phloem lifted to inspect the xylem cylinder for grooving symptoms. A vine to vine survey was made in an eleven-year-old affinity trial on the experimental farm Elsenburg. The trial consists of 22 scion cultivars grafted on 27 rootstock cultivars and crosses (Jacquez $\mathrm{x}$ 99R). A survey was also made in the Chenin blanc on Jacquez vineyard in Paarl where samples for anatomical studies were collected.

Effect on percentage of take and growth in the nursery: In a preliminary trial twenty GSa and twenty GSo two bud Chenin blanc scions were grafted on the same virustested clones of six different rootstock cultivars which indexed free from fanleaf, corky bark, leafroll and fleck. The two-bud scions were collected in the Chenin blanc vineyard in Paarl.

The material was bench grafted manually, callused at $26{ }^{\circ} \mathrm{C}$ for three weeks and planted at random in a sandy loam nursery soil. One year later the vines were uprooted, graded and the wet mass determined. The percentage first grade vines were considered as the percentage take for each combination.

TABLE 2

Survey of GS-symptoms in an 11-year-old-Chenin blanc on Jacquez vineyard in Paarl

\begin{tabular}{|c|c|c|c|c|c|c|c|c|c|}
\hline \multirow{2}{*}{ Vine no. } & \multicolumn{9}{|c|}{ Row no. } \\
\hline & 1 & 2 & 3 & 4 & 5 & 6 & 7 & 8 & 9 \\
\hline 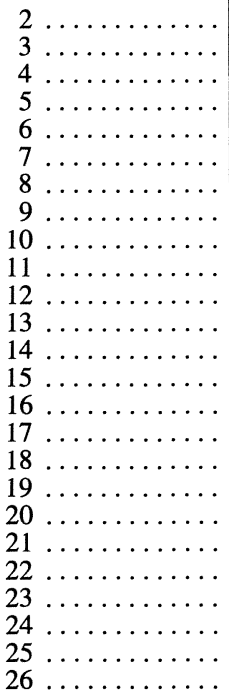 & $\begin{array}{l}+ \\
+ \\
+ \\
0 \\
+ \\
- \\
+ \\
+ \\
- \\
+ \\
0 \\
0 \\
+ \\
+* \\
+ \\
+ \\
0 \\
+ \\
0 \\
- \\
- \\
0 \\
+ \\
+* \\
0\end{array}$ & $\begin{array}{l}+* \\
+ \\
+ \\
+ \\
0 \\
0 \\
+ \\
+* \\
+ \\
0 \\
+* \\
+* \\
+ \\
0 \\
+ \\
0 \\
+ \\
+* \\
0 \\
+ \\
0 \\
+ \\
+ \\
0 \\
0\end{array}$ & $\begin{array}{l}- \\
- \\
0 \\
0 \\
0 \\
- \\
0 \\
+ \\
0 \\
+ \\
0 \\
0 \\
+ \\
+* \\
0 \\
+* \\
+ \\
+ \\
0 \\
0 \\
+ \\
0 \\
+ \\
- \\
+\end{array}$ & $\begin{array}{l}+^{*} \\
+ \\
0 \\
+^{*} \\
- \\
0 \\
0 \\
0 \\
0 \\
+ \\
+ \\
0 \\
+ \\
+ \\
0 \\
0 \\
- \\
- \\
0 \\
- \\
0 \\
- \\
1 \\
0 \\
0\end{array}$ & $\begin{array}{c}- \\
+* \\
+* \\
+ \\
+* \\
0 \\
- \\
0 \\
0 \\
+* \\
+* \\
+ \\
0 \\
+ \\
+ \\
+ \\
- \\
- \\
- \\
0 \\
+ \\
+ \\
0 \\
+ \\
0\end{array}$ & $\begin{array}{c}0 \\
0 \\
- \\
0 \\
+ \\
+ \\
0 \\
0 \\
- \\
0 \\
+ \\
- \\
+* \\
0 \\
- \\
+ \\
0 \\
+ \\
+ \\
+ \\
+* \\
0 \\
0 \\
0 \\
0\end{array}$ & $\begin{array}{c}0 \\
+* \\
+* \\
+ \\
+ \\
+^{*} \\
+ \\
+ \\
+ \\
0 \\
+ \\
0 \\
0 \\
+ \\
+ \\
+* \\
0 \\
+ \\
+ \\
0 \\
0 \\
0 \\
+* \\
0 \\
+\end{array}$ & $\begin{array}{c}+ \\
+ \\
+* \\
+ \\
0 \\
+ \\
0 \\
+ \\
+ \\
0 \\
+ \\
+ \\
+ \\
+ \\
+ \\
0 \\
+ \\
0 \\
+ \\
0 \\
+ \\
+ \\
+ \\
+ \\
+\end{array}$ & $\begin{array}{c}+^{*} \\
+ \\
0 \\
+ \\
0 \\
+ \\
+* \\
0 \\
+^{*} \\
0 \\
+^{*} \\
0 \\
0 \\
+ \\
0 \\
+* \\
- \\
0 \\
0 \\
- \\
0 \\
+* \\
0 \\
+ \\
+\end{array}$ \\
\hline
\end{tabular}

Symbols: $+=$ GSa (114) Stemgrooving diseased

* = delayed (30)

$-=$ GSo (25) Free from stemgrooving

$\mathrm{o}=$ dead and replants (84) 

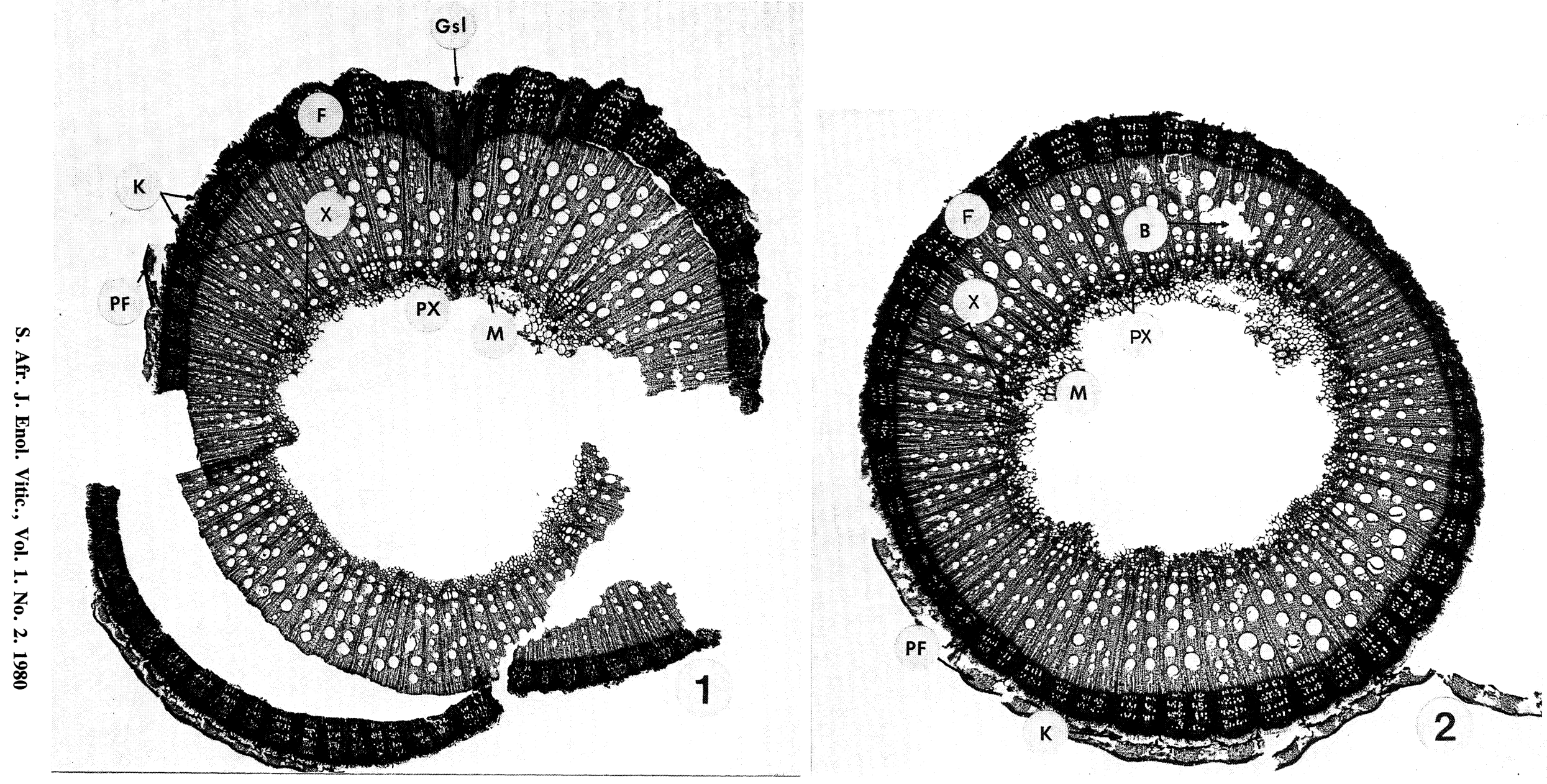

Transverse section of the third internode (basal part) of a one-year old Chenin blanc cane, affected by stemgrooving (GSa). A GS indentation (GSI) is evident in one sector of the xylem (X) and phloem (F). The rest of the section is normal. No symptoms are seen in the pith $(\mathrm{M})$, primary xylem $(\mathrm{PX})$ and primary phloem $(\mathrm{PF})$. The cracks and ruptures in the section are due to the sectioning of the
cane.

FIG. 2.

Transverse section of the third internode (basal-apical) of a healthy (GSo) Chenin blanc cane. All the tissue elements were formed normally. The rupture at $B$ is due to the sectioning. 
Virus indexing: Thirty four GSa vines of six cultivars and 22 GSo vines of four cultivars were indexed during the 1971/72- and 1972/73-growing seasons for leafroll-, corky bark- and fleck viruses, by the Research Institute for Plant Protection using standard procedures and the following indicators:

Virus Indicator

leafroll LN 33 and Mission corky bark LN 33 fleck V. Rupestris var. du Lot

\section{RESULTS}

External and macroscopical symptoms: Budburst of affected vines was delayed by 4 to 5 weeks. Of the 114 inspected GSa Chenin blanc vines 30 showed delayed budburst although all the vines with delayed budburst showed grooving symptoms, as indicated in Table 2 .

The shoot growth of Chenin blanc, Barlinka and Almeria was delayed in spring. This delay was followed by a decline of vigour of the scion cultivars. The decline of vigour was substantiated by the average cane mass of 0,62 and $0,94 \mathrm{~kg}$ per vine over two years respectively for the GSa vines, which was significantly lower than the $1,6 \mathrm{~kg}$ and $2,0 \mathrm{~kg}$ respectively for the GSo vines. Sapflow as indicated by bleeding, was normal on healthy vines whereas no sapflow could be detected in the phloem of diseased vines. Dieback to the graft union as reported by Graniti \& Martelli (1965) could not be substantiated.

An abnormally thick layer of rhytidoma was found on the stem of all infected cultivars. Prominent grooving was perceptible mostly near the graft union when the rhytidoma was removed and the intensity of grooving decreased the further the stem was examined away from the graft union in both directions. When the phloem was peeled off, lengthened ridges and projections were evident on the cambium side, with corresponding grooves and pits on the xylem cylinder. The grooves ran parallel to the longitudinal axis of the stem.

On GSa Queen of the Vineyard and Alphonse Lavallee on Jacquez, the stem of the scion cultivar was thickened abnormally above the graft union, while the rootstock remained thin. No difference in stem diameter of scion and rootstock was found with Chenin blanc, Barlinka and Almeria grafted on Jacquez.

The foliage of severely diseased vines was light green in colour throughout the growing season. The leaves were often smaller, malformed with occasional enation
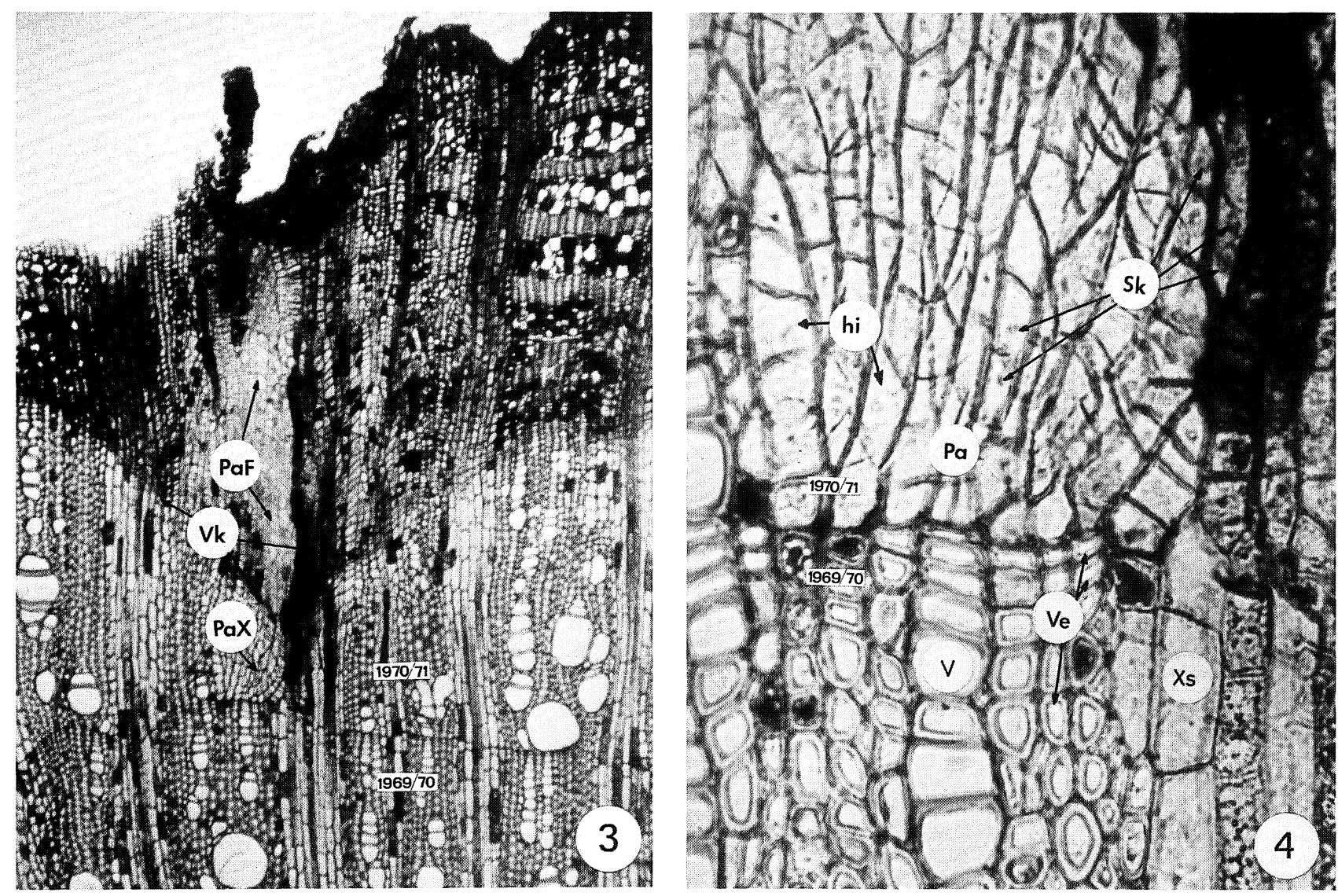

FIG. 3.

Transverse section of an eleven-year-old GSa Chenin blanc/Jacquez stem, $50 \mathrm{~mm}$ above the graft union. The abnormality started in the beginning of the 1970/71 growth layer. A mass of thin-walled, parenchymatic cells were formed in both the phloem $(\mathrm{PaF})$ and $\mathrm{xylem}$ $(\mathrm{PaX})$. More cells were formed centrifugally to the phloem side than centripetally to the xylem side.

FIG. 4.

An enlargement of the beginning of abnormal growth on the border of the growth layer (Fig. 3). Xylem vessels (V), -fibres (Ve) and -ray cells (Xs) were formed normally until the end of the 1969/70 growth layer. Hypertrophy (hi) and parenchymatoses started at the beginning of the 1970/71 growth and thin-walled, malformed parenchymatous cells (Pa) were formed, with prominent nuclei (Sk). No xylem vessels $(\mathrm{V})$ were formed in the infected sector. 
symptons (resembling fanleaf symptons) near the shoot base. In general, smaller and fewer bunches were noticed on GSa vines. On Barlinka, grapes of diseased vines seemed to have less colour than normal vines.

Anatomical symptoms: Anatomical symptoms were generally similar in tissues of various organs of the different cultivars. Abnormalities originally appeared in localized zones within the shoot or stem and gradually spread to neighbouring areas. Therefore, apparently normal and abnormal zones of the same tissue were visible in the same sample. Although similar symptoms were found in the roots, they were less prominent and the study was, therefore, concentrated on stem parts.

Pith: No symptoms were found in the pith. The first symptoms were evident in the cambial zone, soon after secondary growth commenced. (Figs 1 and 2).

Xylem: Symptoms in the one-year-old cane only occurred after some normal secondary xylem derivatives had been differentiated by the vascular cambium. No abnormalities could be detected in the primary xylem. (Figs 1 and 2). No significant difference in tannin content of the cells was visible at this stage. Abnormalities in the secondary xylem were hypertrophy, hyperplasia, hypoplasia and paren- chymatoses of both the tracheid elements and the xylem rays. Fewer xylem derivatives were differentiated in affected areas than in normal areas, (Figs 4, 6, 8 and 9), which gave rise to indentations in the growth layer, (Figs 10 and 11). The xylem derivatives did not differentiate into normal xylem elements, but into enlarged, parenchymatous cells which divided in different directions. These thin walled cells were malformed, arranged irregularly with abnormally large nuclei. Single smaller malformed xylem vessels and fibres were spread between the parenchymatous cells (Figs 6, 8, and 9). Tyloses and gummoses were found in some diseased vessels but it occurred in healthy vessels as well. Abnormal amounts of tannin appeared in drastically affected old xylem (Figs 7, 10 and 11). No difference in the starch content in GSa- and GSo tissues could be detected.

Xylem rays varied in width, they joined and diverged in GSa samples and were not arranged regularly as in GSo samples. In diseased Barlinka, the xylem rays ended in an unorganised mass of undifferentiated parenchymatous cells which stretched over several successive xylem rays, above the graft union. An island of phloem with cork and cutinised cells could be seen within the abnormal xylem tissue. (Fig. 7).
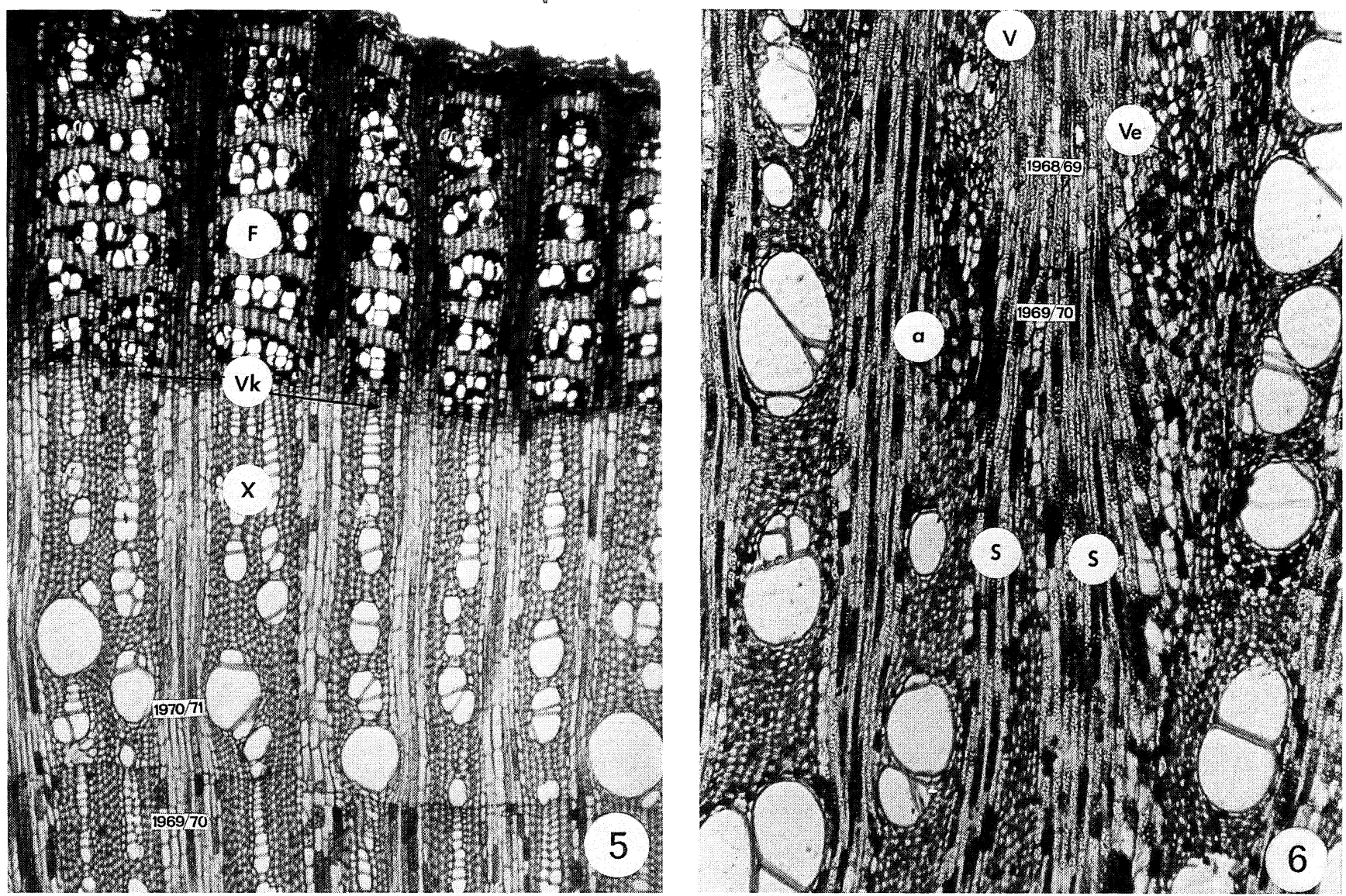

FIG. 5.

Transverse section of a healthy, eleven-year-old Chenin blanc/Jacquez stem, $50 \mathrm{~mm}$ above the graft union. Phloem (F) and xylem (X) elements were formed normally and arranged regularly. The vascular cambium (VK) is clearly visible on the border between the phloem and xylem.

FIG. 6.

Transverse section of the xylem of a diseased Almeria/Rupestris du Lot vine, $50 \mathrm{~mm}$ above the graft union. A mass of unorganised parenchymatous cells is evident in the lesion on the border of the 1968/69 and 1969/70 growth ring. Two xylem rays (S) joined at (a) in the affected sector. Single small xylem vessels (V) and -fibres (Ve) appear scattered. 
Symptoms were more prominent in some years than in others, (Figs 10 and 11). Indents in the layers were more prominent in years with unfavourable growing conditions. Symptoms sometimes disappeared in certain zones in successive growth layers and re-appeared in adjoining zones. Symptoms could be traced in the growth layers for more than 15 years, indicating that the disease had appeared for many years in the Western Cape.

Phloem: No symptoms were observed in the primary phloem and cortex (Fig. 21). In the secondary phloem symptoms were parenchymatoses, hypertrophy and hyperplasia in both the phloem elements and rays. Phloem derivatives, initiated by the vascular cambium did not differentiate into normal phloem elements. Cells divided in all directions and disorderly arranged thin walled parenchymatous cells were formed. Abnormally large nuclei were prominent in the hypertrophic cells, (Figs 3, 5, 8 and 9). Single small malformed sieve tubes, often without any companion cells and fibres, were irregularly distributed between the parenchymatous cells, (Figs 13 and 14). Phloem rays were disorderly arranged, varied in width and sieve tubes and fibres developed in between. In normal zones the bands of phloem sieve tubes and fibres were arranged alternately in an orderly way.

Vascular cambium: No prominent cambium layer was visible in diseased zones. Cells divided in different directions and produced an unorganised mass of undifferentiated parenchymatous cells. No normal differentiation of the cambium derivatives in sieve tubes, companion cells and secondary phloem fibres or xylem elements took place. Different degrees of the symptoms were evident. When phloem and xylem derivatives were produced, they appeared scattered between the parenchymatous cells (Figs 3, 8 and 9).

In the diseased cambium zones cell development was retarded. More phloem-like cells were initiated centrifugally towards the phloem region than were xylem-like cells centripetally towards the xylem region. This might have been the cause of the undulated xylem cylinder (Figs 3, 10 and 11).

When GS symptoms in the xylem cylinder were followed for successive years, there were indications that abnormalities developed in a transversal direction in the cambium zone, because symptoms in a specific radial segment disappeared in successive growth rings and reappeared in adjacent sections (Figs 10 and 11).

The cambium of healthy vines was activated before that of diseased vines resulting in the phloem of healthy vines slipping before that of diseased vines in spring.

Phellogen: In the healthy stem, layers of phloem tissue were cut off annually by periderm arising in successive deeper tissues. In the rays the periderm developed only slightly deeper than in the adjacent phloem elements. In the diseased stem the phellogen followed the topography of the vascular cambium and, therefore, abnormally deep indentations were formed in the phloem rays of abnormal zones which varied in depth according to the different diseased cultivars. As a result considerable sections of only abnormal phloem were cut off, (Figs 15, 16, 17 and 18).

Root: Though less prominent, symptoms similar to that found in the stem were observed in the root. Irregularly arranged, malformed parenchymatous cells with thin walls appeared in the otherwise orderly xylem tissue.

Leaves: No anatomical GS symptoms could be found in leaf petioles and blade tissues. This also indicated that GS is a disease of the secondary tissue.

Susceptibility of cultivars and graft transmission: In June, 1972 one vine each of 99R (Fig. 19) and Constantia Metallica showed prominent visual symptoms similar to corky bark on 8 month old shoots. Typical cracks were found on the nodes and internodes, without the characteristic thickening as described by Beukman \& Gifford (1969) on LN 33.

The appearance of microscopically detectable GSsymptoms on bud-grafted vines is given in Table 3.

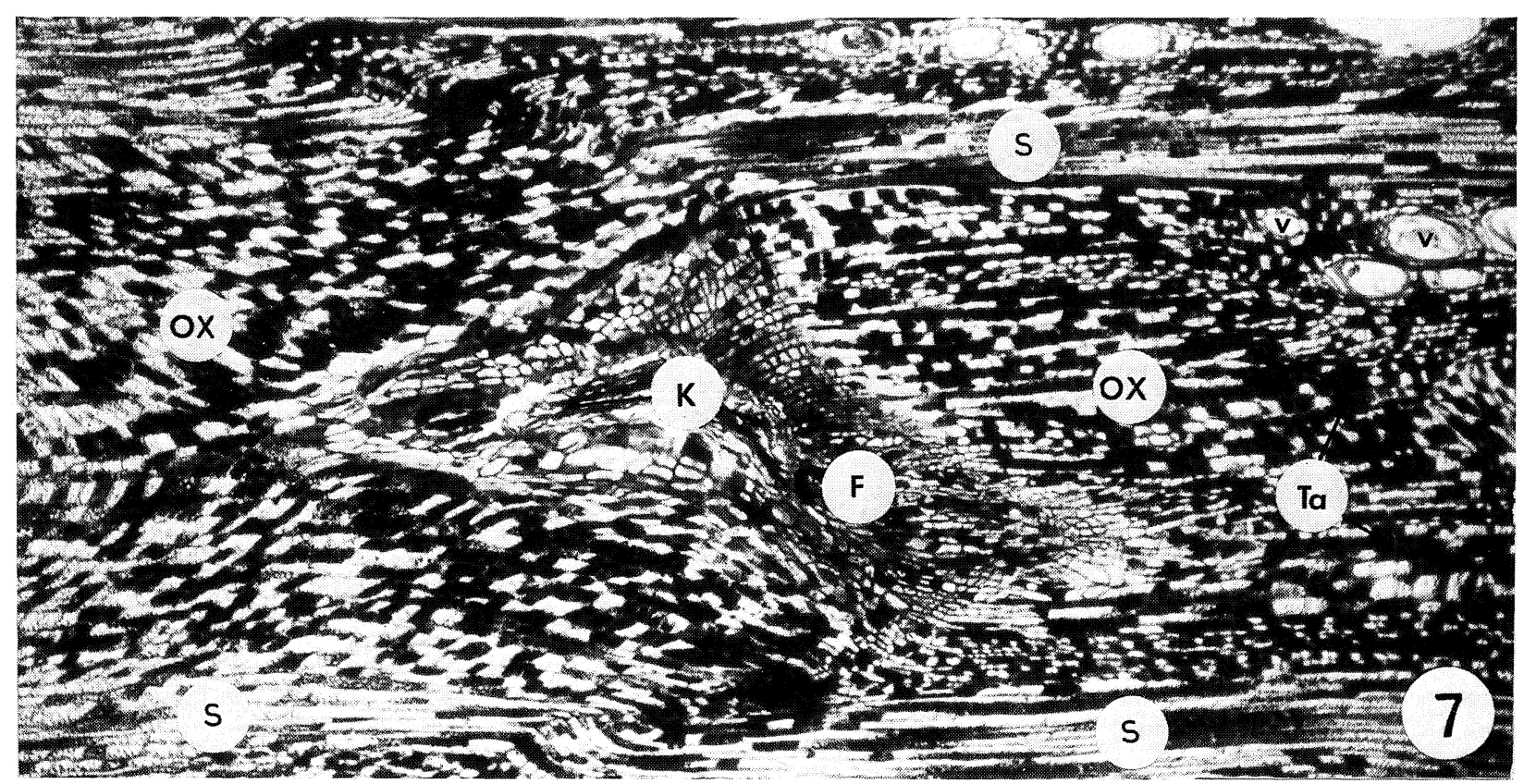

FIG. 7.

Transverse section of the xylem tissue of a diseased Barlinka/Jacquez vine, $600 \mathrm{~mm}$ above the graft union. A phloem island (F) with cork $(\mathrm{K})$ appear at the beginning of a growth layer. Abnormal, undifferentiated xylem tissue (OX) with large amounts of tannin (Ta) were formed around it. The vascular cambium was probably not reactivated in that sector. 
TABLE 4

The percentage of take and mean vine mass of $*$ GSa- and $*$ GSo-graft combinations in the nursery

\begin{tabular}{c|l|l|c|c}
\hline \multicolumn{2}{c|}{ Rootstock } & \multirow{2}{*}{$\begin{array}{c}\text { GS-status } \\
\text { of } \\
\text { Chenin } \\
\text { blanc } \\
\text { scions }\end{array}$} & $\begin{array}{c}\text { Percentage } \\
\text { take } \\
(20 \text { vines })\end{array}$ & $\begin{array}{c}\text { Mean vine } \\
\text { mass (g) }\end{array}$ \\
\hline Jacquez .... & J5/9/24 & GSo & 80 & 57,9 \\
Jacquez ... & J5/9/24 & GSa & 30 & 48,2 \\
C Metallica . & Mel/2/1 & GSo & 30 & 96,0 \\
C Metallica . & Mel/2/1 & GSa & 25 & 76,8 \\
Salt Creek .. & Sc5/19/5 & GSo & 30 & 98,5 \\
Salt Creek ... & Sc5/19/5 & GSa & 25 & 57,6 \\
101-14 Mgt & A1/1/5 & GSo & 15 & 61,4 \\
101-14 Mgt & A1/1/5 & GSa & 5 & 45,3 \\
143-B Mgt.. & B5/32/11 & GSo & 50 & 83,4 \\
143-B Mgt .. & B5/32/11 & GSa & 15 & 84,7 \\
99R ...... & $99 R / 1 / 1 / 13$ & GSo & 40 & 56,4 \\
99R ...... & $99 R / 1 / 1 / 13$ & GSa & 45 & 41,2 \\
\cline { 2 - 3 } & & GSo & & \\
& & average & 40,8 & 75,6 \\
\cline { 2 - 3 } & & GSa & & \\
& & average & 24,2 & 52,9 \\
\hline
\end{tabular}

$* \mathrm{GSa}=$ Stemgrooving diseased

$* \mathrm{GSo}=$ Free from stemgrooving
Virus indexing: Indexing results are given in Table 5 which indicate an apparent relationship between corky bark and GS. No such relationship could be found between GS and leafroll or between GS and fleck.

\section{DISCUSSION AND CONCLUSIONS}

Results indicate that the disease has been present in the Western Cape for many years, and it is evident that in years with difficult growing conditions the symptoms were more severe. The external symptoms of stemgrooving in Chenin blanc, Barlinka and Almeria resemble those described by Graniti and Martelli (1965) on Primitivo di Gioia in Italy. However, budburst was not delayed in all vines with GS symptoms, probably indicating the presence of additional factors.

The anatomical study revealed that GS is a disease of the secondary tissue only. No symptoms were found in the pith and primary tissues. Symptoms initially arose in the cambial zone after secondary growth commenced. Abnormal derivatives were formed by an abnormal functioning vascular cambium. This resulted in hypertrophy, hyperplasia, hypoplasia and parenchymatoses in both the secondary xylem and phloem. Abnormal quantities of

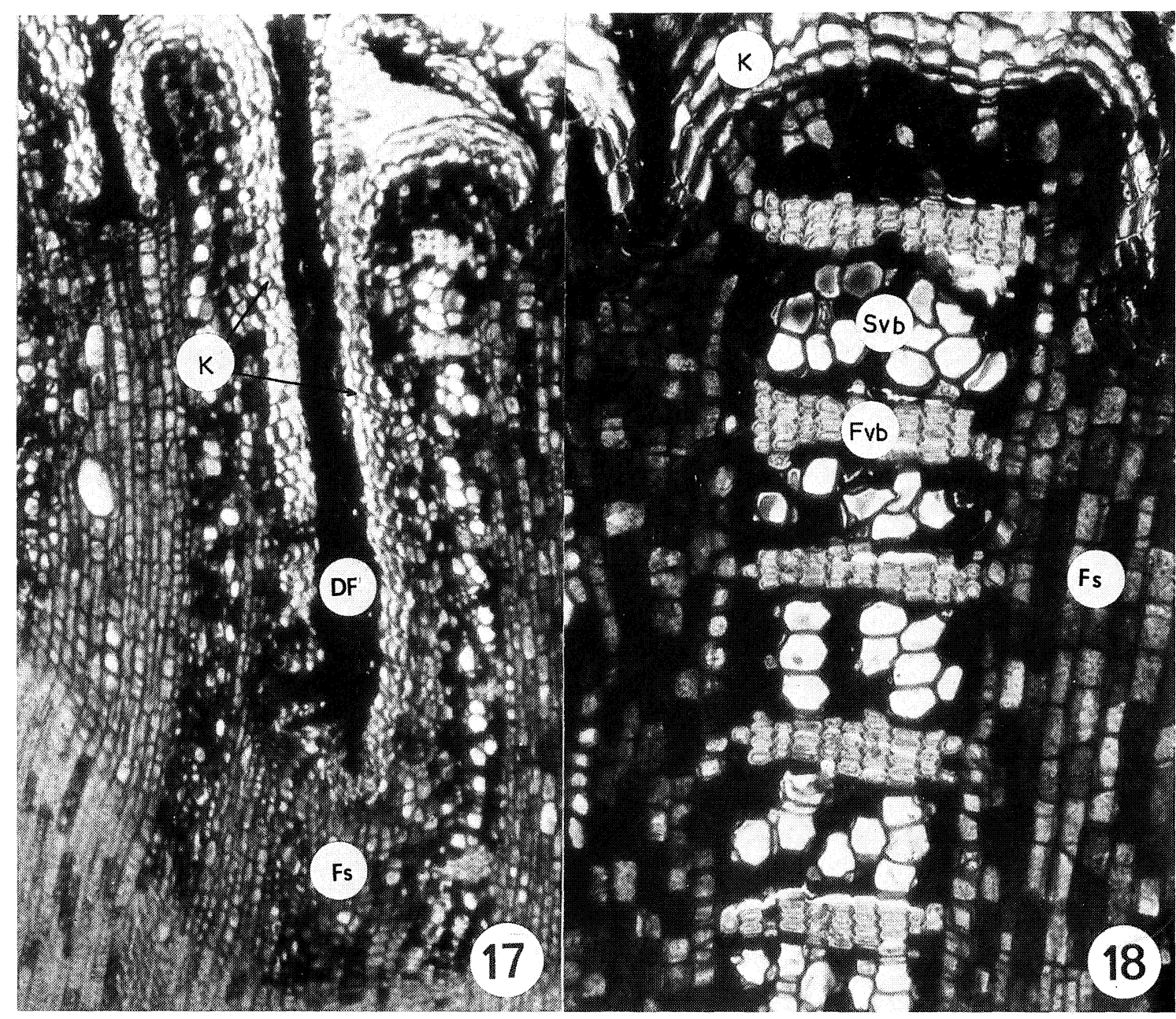

FIG. 17

Transverse section of a diseased Almeria/Rupestris du Lot vine, $10 \mathrm{~mm}$ under the graft union to indicate the abnormal phloem and cork layer (K). The cork forms abnormally deep in the phloem ray (Fs.). $\times 72$

FIG. 18

Transverse section through the normal phloem segment of the same vine as in Fig. 17. The cork layer $(\mathrm{K})$ formed regularly in the phloem and cut off the older tissue. Svb: tangential bands of sieve tube elements; Fvb: tangential band of phloem fibres. $\times 200$ 
TABLE 5

Virusindexing results of visually GSa*- and GSO*-vines for the 1971/72 and 1972/73 growing seasons

\begin{tabular}{|c|c|c|c|c|c|c|c|c|c|c|}
\hline \multirow{2}{*}{ GS-status } & \multirow{2}{*}{$\begin{array}{l}\text { Number } \\
\text { of vines } \\
\text { indexed }\end{array}$} & \multicolumn{3}{|c|}{ Corky bark } & \multicolumn{3}{|c|}{ Leafroll } & \multicolumn{3}{|c|}{ Fleck } \\
\hline & & Positive & Negative & Dead & Positive & Negative & Dead & Positive & Negative & Dead \\
\hline $\begin{array}{l}\text { GSa } \ldots \ldots \ldots \ldots \\
\text { GSo } \ldots \ldots \ldots \ldots\end{array}$ & $\begin{array}{l}34 \\
22\end{array}$ & $\begin{array}{c}21 \\
61,8 \% \\
1 \\
4,5 \%\end{array}$ & $\frac{0}{20}$ & $\begin{array}{c}13 \\
38,2 \% \\
1 \\
4,6 \%\end{array}$ & $\begin{array}{c}27 \\
79,4 \% \\
22 \\
100 \%\end{array}$ & $\begin{array}{c}1 \\
2,9 \% \\
0 \\
-\end{array}$ & $\begin{array}{c}6 \\
17,7 \% \\
0 \\
-\end{array}$ & $\begin{array}{c}26 \\
76,5 \% \\
19 \\
86,4 \%\end{array}$ & $\begin{array}{c}6 \\
17,5 \% \\
2 \\
9,0 \%\end{array}$ & $\begin{array}{c}2 \\
6 \% \\
1 \\
4,6 \%\end{array}$ \\
\hline
\end{tabular}

*GSa $=$ Stemgrooving diseased

${ }^{*} \mathrm{GSo}=$ Free from stemgrooving

parenchymatous phloem tissue were formed centrifugally at the cost of centripetal xylem production. The normal cambium produced normal xylem and phloem tissues in zones adjacent to the diseased tissues. The occurrence of normal and abnormal zones adjacent to one another explains the undulated appearance of both the vascular cambium as well as the surface of the xylem cylinder. The abnormal hyperplastic phloem formed the ridges on the cambium side of the bark, which fitted into corresponding grooves in the xylem cylinder. The cork cambium followed the same topography as the vascular cambium and originated abnormally deep in the affected phloem rays. Therefore, abnormally large quantities of infected phloem was sloughed off, and when the rhytidoma was removed, grooves were also visible on the outer surface of the phloem.

The abnormal functioning of the vascular- and cork cambium may be ascribed to the presence of GS-factor(s) in the cambium zone. According to Esau (1956) viruses can cause abnormalities in cells by means of an interaction with the biochemical gradients of several processes. The cambium abnormalities might also been caused by products of an abnormal metabolism, the latter induced in remote zones by the GS-factor(s) (McKinney and Hills, 1941). There were strong indications that the factor(s) responsible for the symptoms may be transmitted in the cambial zone. This was illustrated by the observation that when anatomic symptoms were followed in successive growth rings they proceeded in a transversal direction in the xylem cylinder and the radial continuation of affected sections became normal. Although anatomical symptoms were detected below the graft union in the transmission trials, they mainly appeared above it, possibly indicating a stronger apical movement of the factor(s) responsible for the symptoms. The disease probably belongs to the histological unrestricted group of virus- and virus-like diseases (Esau, 1961), because symptoms appeared in the phloem, xylem, cambium and cork cambium. Graniti and Martelli (1965) only detected symptoms after two to three years and then only in the vicinity of the graft union. In this study symptoms were detected microscopically on shoots early after secondary growth commenced and even within six months after budgrafting in the transmission trials.

Symptoms in the phloem corresponded closely with those described by Beukman \& Gifford (1969) for corky bark on LN 33. The main differences were the undulated vascular cambium and the presence of cork cambium in GS infected vines. Although less xylem than phloem was formed for both GS and corky bark, the xylem was normal in corky bark infected LN 33. In a preliminary indexing trial an indication of a correlation between the presence of
GS and corky bark was found. This relationship was substantiated by the visual and microscopical observation of corky bark-like symptoms on C. Metallica budded with GSa material. Due to the probable relationship between corky bark and leafroll (Goheen, 1968), leafroll may also be involved in the manifestation of GS symptoms. GS symptoms may be caused by a combination of viruses or viruslike factors of which corky bark and/or leafroll are important components.

In Pierces' disease, also a disease of the secondary tissue, tyloses and gumming were induced in the vessels of infected xylem (Esau, 1956), whereas this was not found in GS infected vines.

No anatomical evidence could be found for the suggestion by Hewitt (1970) that fanleaf may be involved in the manifestation of GS symptoms. No trabeculae were evident in cells of GSa tissue as was in the case of fanleaf (Graniti and Russo, 1965). GS symptoms differ from leafroll in that leafroll symptoms are also displayed by primary tissue (Hoeffert and Gifford, 1967a). GS symptoms correlating with that of "Flavescence dorée", (Caudwell, 1965), are the irregular distribution of phloem fibres, the production of abnormally large amounts of phloem at the cost of xylem and the cork layer originating abnormally deep in the phloem tissue. However, the two diseases differ in some aspects. In GSa tissue the symptoms were confined to delimited areas, whereas in "flavescence dorée" infected tissue, it appeared over vast areas. With flavescence doree infection the pith also enlarged.

According to Engelbrecht \& Nel (1971) -the delayed budburst may be caused by an abnormal functioning of the phellogen which supposedly would slough off large amounts of secondary phloem. However, in this study it was found that the phellogen only originated abnormally deep in the phloem rays. Therefore, no functioning sieve tubes could be sloughed off. Furthermore, in diseased areas no normal functioning sieve tubes were formed. Lehoczky's (1970) proposal that the delayed budburst may be the result of the malfunctioning conductive tissue was substantiated by this study. The intensive anatomical changes in the phloem- and xylem tissues may influence the flow of metabolic products and nutrients. It was evident that sapflow started later in the diseased, retarded vines, however, this could not be ascribed to gummoses and tyloses. The delayed budburst may also be physiological in origin, because the presence of GS-factor(s) may induce an abnormal hormonal balance and subsequent abnormal physiology (Esau, 1956).

Although field observations in Italy (Graniti \& Martelli, 1970) and Greece (Agrios, 1971) indicated a possible soil transmission of the disease, no such indications could 
Stemgrooving (Legno Riccio)



FIG. 19

A 99R vine in June, 1972. The vine was rooted in August 1971 and budgrafted with a GSa Chenin blanc bud (GSa) on October 12. Severe corky bark-like symptoms (Skb) can be seen on the one-year-old cane.

FIG. 20

Transverse section through the first internode (basal-apical) of a one-year-old 99R vine, budgrafted with GSa-Chenin blanc (No. 1, Fig. 19). Formed xylem- (Xd) and phloem derivatives (Fd) did not differentiate further into vessels and sieve tubes respectively in affected zones. Cork (K) was formed continuously. Ko: Cortex. 


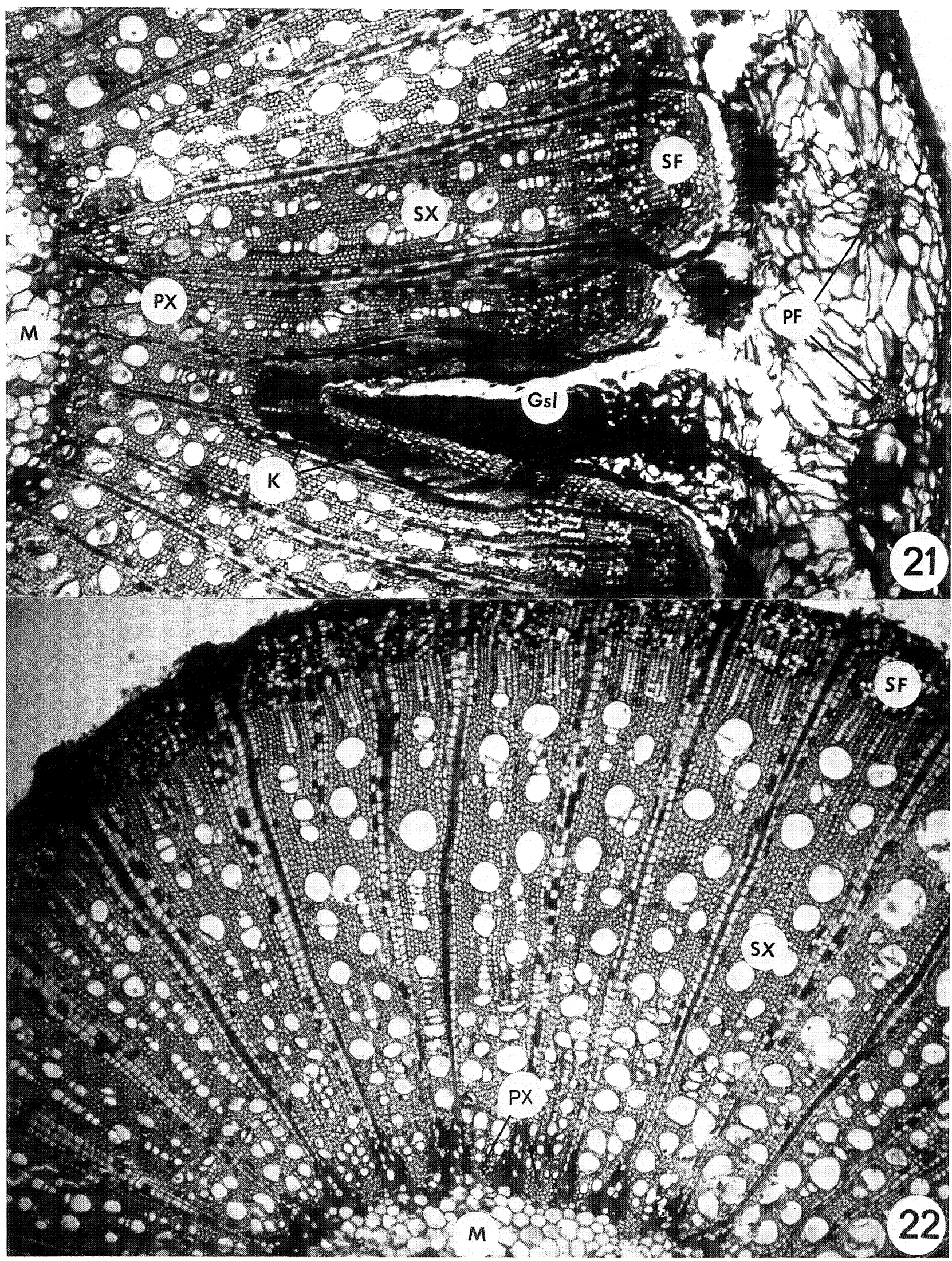
FIG. 21

Transverse section of the third internode (from base) of the one-year-old cane (No. 3, Fig. 19) of a 99R vine, budgrafted with a GSa Chenin blanc bud. The start of the symptoms can clearly be seen. The pith (M), primary xylem (Px) and -phloem (PF) are normal. The cork layer (K) originated abnormally deep in the phloem (F) and caused the indentation (GSI). SX: Secondary xylem. $\quad \times 60$ FIG. 22

Transverse section of the first internode (basal) of a one-year-old cane of the control 99R vine, budgrafted with a healthy Chenin blanc bud. Note the normal, regular arrangement of the tissue elements. 



FIg. 23

An example of two 99R vines which were budgrafted 18 months ago. The vine on the left was budgrafted with a GS-diseased bud (GSa) and the one on the right with a bud free of GS (GSo).

FIG. 24

Transverse section of the three-year-old stem of a GSa C. Metallica vine, $20 \mathrm{~mm}$ above the bud union in June, 1973. The vine received the same treatment as the 99R vine in Fig. 19 and was budgrafted with a GSa Chenin blanc bud in October, 1971. Both stemgrooving (GsL) and corky bark (Skb) symptoms appeared in the third year's growth, two years after budding. At "a" a combination of corky bark and GS-symptoms is present. 

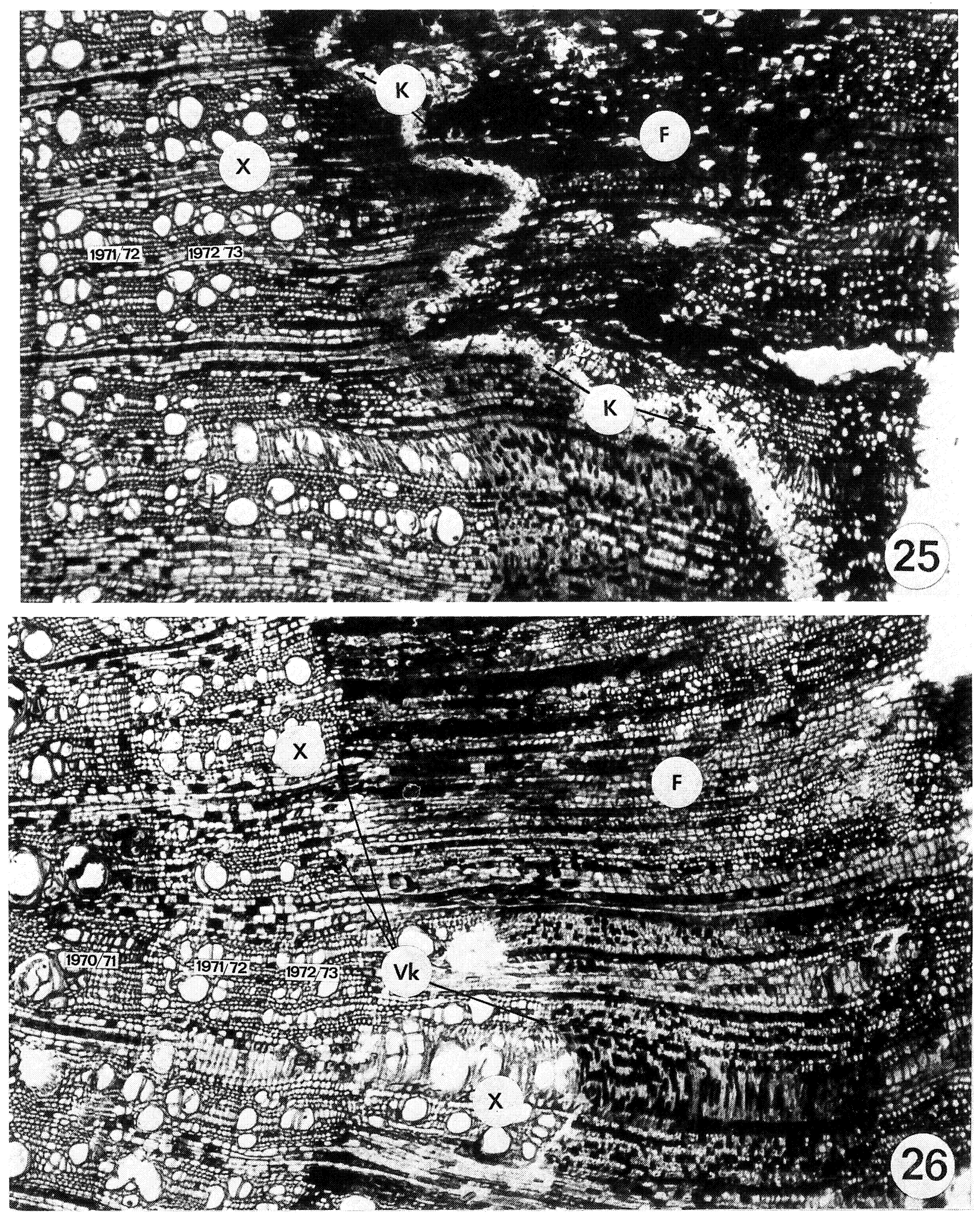

Fig. 25

An enlargement of the tissue segment at "a" in Fig. 24 to indicate the combination of GS- and corky bark symptoms. An abnormal cork layer $(\mathrm{K})$ was formed. Large quantities of abnormal phloem tissue $(\mathrm{F})$ were formed at the expense of xylem $(\mathrm{X}) . \quad \times 70$

FIG. 26

An enlargement of a tissue segment in Fig. 24 to indicate the typical corky bark symptoms (Skb). Abnormally large quantities of phloem $(F)$ were formed at the expense of xylem (X). The vascular cambium (Vk) is difficult to distinguish. No cork layer is present in the wide phloem zone. Formed xylem is normal. 
be found in preliminary surveys (Table 2). The most important means of transmission appeared to be by the process of grafting. Because stemgrooving reduces the percentage of take and growth in the nursery, the fact that such poor material is automatically discarded, may be a factor in restricting the spread of this disease.

\section{LITERATURE CITED}

ABRASHEVA, PENKA \& TSVETANOV, D., 1970. A new virus disease of grapevine in Bulgaria. Rastit Zasht. 18, 25-28 Rev Plant Path 49, 371.

AGRIOS, G. N., 1971. A stempitting disease of grapevine in Greece. Pl. Dis. Reptr. 55, 869-871.

BEUKMAN, E. F. \& GIFFORD, E. M., Jr., 1969. Anatomic effects of corky bark virus in Vitis. Hilgardia 4, 73-103.

BROOKES, R. M., BRADLEY, M. V. \& ANDERSON, T. I., 1963. Plant Microtechnique Manual. University of California, Davis, 4th ed., 70 pp.

CAUDWELL, A., 1965. Reactions of host plants to Flavescene dorée virus. Proc. int. conf. on virus and vector on perennial hosts with special reference to vitis. 126-135. Davis California.

DE VOS, M. P., 1962. B. Honneurs: Mikrotegniek.

ENGELBRECHT, D. J. \& NEL, A. C., 1971. A grafttransmissible stem grooving of grapevines in the Western Cape Province (South Africa) resembling legno riccio (rugose wood). Phytophylactica 3, 93-96.

ESAU, K., 1956. An anatomist's view of virus diseases. Amer. Jour. Bot. 43, 739-748.

ESAU, K., 1961. Plants, viruses and insects. Cambridge, Mass: Harvard Univ. Press, $110 \mathrm{pp}$.

GOHEEN, A. C., 1968. Virus Test auf Corky Bark in den USA. Weinberg $u$ Keller 15, 510-514.

GRANITI, A., 1964. Note sintomatologiche e estologiche sulle viti affette da legno riccio. Phytopathol. Medit. 3, 19-25.

GRANITI, A., \& MARTELLI, G. P., 1965. Further observations on legno riccio (Rugose Wood). A graft-transmissible stem pitting of grapevine. Proc. int. conf. on virus and vector on perennial hosts with special reference to vitis. 168-179. Davis, California.

GRANITI, A., \& RUSSO, M., 1965. Some observations on endocellular cordons (trabeculae) in fanleaf-affected grapevines. Proc. int. conf. on virus and vector on perennial hosts with special reference to Vitis. 271-281. Davis, California.
GRANITI, A. \& MARTELLI, G. P., 1970. Legno riccio. Virus diseases of small fruits and grapevines. University of California Press, Berkeley, California. 1970. 243-245.

GUENGERICH, H. W. \& MILLIKAN, D. F., 1956. Transmission of the stem pitting factor in apple. Pl. Dis. Reptr., 40, 934-938.

HEWITT, W. B., 1965. Pierce's disease of the grapevine. Proc. Int. Conf. on virus and vector on perennial hosts with special reference to Vitis. 117-125, Davis, California.

HEWITT, W. B., 1970. Connaissances actuelles sur les viroses de la vigne. Repartition geographique, symptômes, propriëté des virus, mode de transmission. Bull. de L'OIV 1971. 44(480), 97-125.

HEWITT, W. B. \& NEJA, R., 1971. Grapevine bark and wood pitting disease found in California. Pl. Dis. Reptr. 55, 860-861.

HOEFERT, L. L. \& GIFFORD, E. M. (jr.), 1967a. Grapevine leafroll virus History and anatomical effects. Hilgardia 38 , $403-426$.

JOHANSEN, D. A., 1940. Plant Microtechnique. New York: McGraw-Hill, Inc. 523 pp.

KRIEL, G. J. le R., 1973. Simptomatologie en anatomie van gleufstam (legno riccio) by die wingerdstok (Vitis). M.Sc. Agric thesis, University of Stellenbosch

LEHOCZKY, J., MARTELLI, G. P., SAROSPATAKI, G. \& QUACQUARELLI, A., 1968. "Neue Beobachtungen am 'legno riccio' der Reben in Ungarn.' Weinberg u. Keller $15,506$.

LEHOCZKY, J., 1970. Destructive effect of legno riccio (rugose wood) on European grapevine varieties. I.N.R.A. Publ. 72-74, 59-65, 1972.

McKINNEY, H. H. \& HILLIS, C. H., 1941. Mosaic cholorosis and necrosis in virus-infected perennial pepper caused directly by products of a deranged metabolism. Science 94 , 372-373.

MIRCETICH, S. M., FIGLE, H. W. \& BARRAT, J. G., 1968. Further observations on stem pitting in Prunus. Pl. Dis. Reptr. 52, 287-291.

OBERHOLZER, P. C. J., MATHEWS, I. \& STIEME, S. F., 1949. The decline of grapefruit trees in South Africa. A preliminary report on so-called "stem pitting." Sc. Bul. Dept. Agr. Far. Un. S. Afr. 297, 1-18.

VUITTENEZ, A., 1970. Méthode de diagnostic des viroses de la vigne. Bull. de L'OIV 475, 928-929. 